\title{
Economizing Justice: turning equity claims into lower energy tariffs in Chile
}

(This paper appears the journal Energy Policy, 2017, 105, pg.642-647

https://doi.org/10.1016/j.enpol.2017.02.013)

\section{Carla Alvial Palavicino \& Sebastián Ureta}

Núcleo Milenio de Investigación sobre Energía y Sociedad

Departamento de Sociología

Universidad Alberto Hurtado

Santiago, Chile

\section{Abstract}

This paper considers the issue of how energy justice is economized; how political and ethical claims about particular energy (in)justices are turned into economic valuations. Drawing on science and technology studies, we present a conceptual framework that understands economization as emerging from three interrelated processes: problematization, framing and overflowing. Applying this framework to the drafting of new energy legislation in Chile, we trace how perceived shortcomings in equity and distributional justice were turned into "market failures," able to be resolved by market-based mechanisms. This case highlights the dangers implicit in the uncritical economization of energy justice claims, in which ethical considerations regarding the distribution of risks and benefits of energy production and provision are reduced to a redistribution of payments among consumers - something that limits the possibilities for structural reform.

Keywords: energy justice, equity, economization, tariffs, valorimeters

\section{Introduction}

Emerging from the encounters between energy research and environmental justice, the concept of energy justice (EJ) has, in recent years, gained momentum. Concerned with "how negative environmental and social impacts related to energy are distributed across space and time, including human rights abuses and the access that disenfranchised communities do or should have to remedies" (Sovacool \& Dworkin 2015, p.441), this area of research studies the particular arrangements that produce these negative consequences, developing strategies that can remedy or overcome such.

This paper contributes to the development of this area of research by exploring one issue that has not been analyzed: how are energy justice claims enacted into regulation and policy? This question derives from the recognition that energy policy and regulation "has to-date been in part unsuccessful in relation to delivering an overall positive societal contribution or impact" (Heffron \& Talus 2016, p.4). As such, there is a clear need to better understand the processes by which justice claims are mobilized into regulation, focusing in particular on the failures and unanticipated developments that diminish the capacity of policy and legislation to enact more just energy systems.

Seeking to answer this question, we present a case study of the development of a particular regulation called "Ley de equidad tarifaria en servicios eléctricos" ("Law for tariff equity in electrical services"). Enacted in Chile in June 2015, this law introduced a standard of justice on 
the prices paid for electricity, reducing the difference between urban and rural end-users. However, the intended outcome of this regulation went far beyond price correction. As explained by President of Chile Michele Bachelet during its launch on 15 June 2016, this regulation looked "to install a new view about the country that we want to be and should be: a solidary community, where costs and benefits are distributed in a more equitable way". The law proposed a new version of Chile, a more egalitarian community, with a more even distribution of energy costs - also a central concern of EJ literature.

In analyzing the development and discussion of this regulation, and given its intent to correct energy price imbalances, we focus on how equity claims are enacted as economic issues in a policy context. In this, we use an analytical framework based on conceptual developments made in science and technology studies (STS), particularly the social studies of finance and markets. As with STS research on other scientific disciplines and forms of knowledge, this approaches economics as a form of "politics by other means" (Latour 1983). Economic knowledge and economic practitioners do "not simply represent the economy, but [are] constitutive of economic institutions, including the economy, markets, and economic agents" (Breslau 2013). Economic knowledge, in other words, is "performative" (MacKenzie 2007), enacting particular "economic" states of the world. Following this, we introduce an element key to understanding the policy implications of justice claims: specifically, how particular forms of economics behind justice claims are mobilized into policy.

This paper is structured as follows: in the next section, we introduce the concept of 'economization' and explore its relation to energy justice in a policy context. We then present our methods and case study, before analyzing the "tariff equity law" as an economization of (energy) justice demands, the result of processes of problematization, framing and overflowing. Finally, we discuss wider applications of the economization perspective on energy justice, in both academic and policy contexts.

\section{Energy, equity and economizations}

Equity is at the heart of energy justice. One of the main issues when analyzing this concept is the way in which, in everyday conversation, "equity is often confused with, or used synonymously with, a variety of other concepts such as fairness, justice and equality" (Le Grand 1991, p.7). In more theoretical and technical work, however, equity is clearly delineated both from equality and justice. Lacking the descriptive element of the former (Le Grand 1991, 11 ) and the general inclusivity of the latter (Ikeme 2003), equity is understood as a distributive issue, referring to the allocation of benefits and costs of particular arrangements among those involved.

This is the approach taken in the EJ literature, which defines equity "in terms both of access to affordable, safe and reliable energy and of the distribution of the risks and benefits of new technologies" (Hall et al. 2013, p.415). Specifically, equity has been framed in terms of distributive justice, focusing on "how energy harms and energy services are distributed, whether the energy system is equitable or not and whether it is fair to future generations or not" (Sovacool \& Dworkin 2015). Issues of equity "often relate to the politics of energy production, particularly in relation to the siting of existing energy facilities and the development of new energy infrastructures" (Fuller \& McCauley 2016, p.2), along with concerns about "access to energy services" (Jenkins et al. 2016). In this, equity is paired with issues of procedural and recognition justice, with the understanding that inequities "are not matters only of prices and income, but of structural differences that are produced and reinforced over time and through space" (Hall et al. 2013). 
However, this extended notion has not seen significant uptake in policy contexts, where equity is still "commonly limited in its conceptualisation to accessibility and affordability of energy supply" (Tomei \& Gent 2015, p.72). This framing is derived from the traditional aim of sociallyminded policy interventions, which have focused "on access to affordable electricity as a means of enabling broad participation in markets and civil society" (Welton 2016, p.30). Beyond concerns of procedural or recognition justice - and even extended notions of distributional justice - the role of equity claims in energy policy have been limited to the safeguarding of "markets, security of supply and efficiency. It is about government policies aimed at securing energy sources at the least possible cost, including social cost" (Heffron \& Talus 2016).

This particular understanding of equity is a result of the fact that, for most countries, "energy policy remains a largely techno-economic problem" (Miller et al. 2015, p.29). In practice, this approach usually entails a division in which all material issues are treated as purely technical, while the social dimensions are reduced to economics. Even if intervention is motivated by political or cultural concerns, "economic frameworks allow that intervention to be formulated and justified in terms of the efficient functioning of a system - the economy - rather than as resource transfers on behalf of one or another social group" (Breslau 2013). In this, we can see how economics and energy policy reinforce each other: although economics has been able to simultaneously identify and correct for some of the weaknesses of existing energy systems, the regulation of "electricity ... has become a vehicle for the expansion of the economic grid into previously non- or semieconomic domains" (Özden - Schilling 2015).

Consequently, in order to be treated as valid policy issue, equity demands must be "economized". Caliskan and Callon (2009; 2010) understand economization as the process by which "the behaviours, organizations, institutions and, more generally, the objects in a particular society which are tentatively and often controversially qualified ... as 'economic'" (Calıskan \& Callon 2009). Building on previous work by Callon and others (Callon 1998; Callon et al. 2007; MacKenzie 2007), economization comprises three interrelated processes: problematizing, framing and overflowing.

Following Latour (2004), problematizing denotes the processes by which stable matters of fact are turned into matters of concern - "those things and situations that - for better or worse are related to us, can affect us and worry us in the current context of liberal market democracies" (Geiger et al. 2014, p.2). The process through which matters of concern are then economized involves framing, establishing economic "frames" (Callon 1998) ${ }^{1}$ that surround and contain those entities under consideration, cutting existing ties with other entities. These frames forge new relations between the entities inside the frame, often through quantification. Through these processes of problematization and framing, a particular market is enacted, a "space of calculability" (Ibid.) in which relations are qualified in price terms. However, these processes are never straightforward or automatic. Attempts at framing are beset with multiple overflowings, from entities who resist the severing of relations and emerging agencies with unexpected behavior. An important part of the work of economization rests on dealing with the multiple frictions emerging from framing processes and the overflowings of heterogeneous matters of concern.

In deploying this model, we can see how the economization of equity within the energy sector follows this triple movement. First, through processes of problematization by which justice

\footnotetext{
${ }^{1}$ It is important to note, however, that to establish an economic framing out of a problematization is only one of the many ways in which we could deal with a matter of concern (see for example Schaeffer \& Smits, 2015).
} 
claims linked to energy production, distribution and consumption are turned into matters of concern, as "inequities" needing to be addressed. These processes are undertaken by a heterogeneous group of actors, from NGOs to the media, deploying a range of practices and devices, from protest and demonstrations to policy proposals.

Secondly, and following the economic usage of the concept (Le Grand 1991), the inequities of the energy system are framed as different kinds of "externalities". Inequity is enacted as an imbalance between "the distribution of 'goods' and 'bads' ... and the principles by which these benefits and burdens are, or should be, distributed" (McDermott et al. 2013, p.418). The solution to these issues appears as a matter of devising a relocation of costs and benefits to correct - or mitigate - the externalities. To govern this relocation, the draft bill introduces several "market devices" (Callon et al. 2007) ranging from taxes to subsidies. Their introduction is expected to correct the externality and, in doing so, alleviate the underlying inequity.

Such a neat outcome, however, rarely happens. To begin with, we discard the notion of markets as merely rational arrangements, and instead consider them as "explicitly moral projects, saturated with normativity" (Fourcade \& Healy 2007, p.299). This is because "market exchange ... involves more or less conscious efforts to categorize, normalize, and naturalize behaviors and rules that are not natural in any way, whether in the name of economic principles (e.g., efficiency, productivity) or more social ones (e.g., justice, social responsibility)" (p. 300). This is particularly true of the energy sector, where "framing is fundamentally intertwined with ... normative claims" (Fuller \& McCauley 2016); claims that are multiple and, often, contradictory. As a consequence, attempts to frame justice claims in the energy sector as conventional market failures are crosscut by multiple overflowings in the form of entities that resist being framed in a purely rational fashion.

As a result of these various framings and overflowings, economization processes produce multiple results. In some cases, they might maintain - or even exacerbate - the justice claims motivating the intervention. In others, they can transform the situation for the better, enacting "civilized" energy markets (Callon 2009) that consider and value the normative matters of concern, including justice claims, implicated in their activities. Given that such markets explicitly address the "struggles where actors tap into different principles of justice or explanations of what is good" (Geiger et al. 2014), they have better chances of delivering arrangements in which such concerns are properly addressed.

\section{Methods}

To analyze the relation between economization and justice in an energy policy context, we made a case study of the parliamentary discussion of a bill designed to achieve electricity tariff equity in Chile. This discussion is the key final step in the drafting of a new law or regulation, where different framings and political interests are made visible.

We obtained a transcript of the discussion of this particular bill (known as law № 20.928) from the Chilean Library of Congress (www.ben.cl). Comprising three rounds of discussion in the Senate and Deputy Chambers of Congress, deliberation took place between 1 July 2015 and 31 May 2016.

To analyze the parliamentary discussion, we used a grounded theory approach (Suddaby 2006) to understand how actors make sense of equity issues relating to energy. We manually coded the discussions for issues related to justice, paying particular attention to appearances of the economization framework. This entailed an open categorization, approaching the material with no pre-established categories, instead, constructing such as the empirical data was 
analyzed. The first round of analysis and coding provided categories including: local community, access, price, externalities, taxes, and so on. Following this, we coded subcategories around a common axis, grouping them in terms of their commonalities and differences as a means of identifying "overflowings." For example, codes such as consumer, price, cost, and access followed the logic of economization guiding the law, while codes such as community, infrastructure, externalities, did not clearly follow the logic, and can be classified as as "overflowings". Finally, we established a central categorization that became the explanatory framework of the process of the bill's economization, organizing categories in terms of their coherence with the rationale of the law, and identifying those excluded. Using this explanatory framework, we reconstructed the processes by which a particular framing of energy equity was transformed into a series of proposals for economic valuation devices during the parliamentary process.

Our analysis of the transcript was supplemented by a close reading of associated documents, including official energy policy publications, draft pills, and reports from civil society and international organizations (IEA, OECD, GIZ) - all published in the period between initial electricity liberalization reform and the conclusion of our research (1982-2016). This search was conducted by tracing chains of references between documents, supplemented with material from a pre-existing database associated with energy controversies in the Chile developed by one of the paper's authors in the context of a separate research project. This complementary search was intended to provide a context of recent discussions of energy justice and equity issues, with several of these documents cited during parliamentary discussion of the electricity tariff equity bill under analysis.

\section{The case: Chile's "tariff equity law"}

\subsection{Problematizing}

The Chilean energy system has undergone a series of important economic, technological and regulatory transformations since the early 2000s. Initially, these reforms were responding to a series of crises in energy supply, resulting from a substantial decrease in the amount of imported fossil fuels (mainly natural gas from Argentina, see Huneeus 2007). As a result, energy prices grew considerably from the mid-1990s, something that particularly affected small and household consumers. This played a significant role in the emergence of "equidad" (equity) as a matter of concern within the policy domain. Raised in the mid-1990s by NGOs working on poverty issues (CNSP 1996), from the early 2000s, the issue was taken up by environmental activists and NGOs (Wautiez \& Llavero 2002; Castillo \& Maldonado 2004), who focused on the role of high energy prices paid by low-income and rural populations. Importantly, for these actors, the concept of equity - invoked to express a concern about distributive justice - was always linked with other types of justice claims, particularly demands for a more democratic and participatory energy system.

These demands for greater levels of equity in the Chilean energy system challenged the dominant framing of energy as certain "markets" determined by laws of "efficiency". As part of the programme of neoliberal reforms carried out under the Pinochet dictatorship, in 1978 a series of radical deregulation policies were introduced in the energy sector, focusing particularly on electricity provision (Bernstein 1988). At the heart of these reforms was the privatization and unbundling of energy companies, creating a system based on competition between multiple private actors, with a limited, subsidiary role for the state. However, undercutting the reform's stated aim of "liberalizing" its agents, residential consumers remained subject to regional distribution monopolies, forced to accept the prices assigned to specific distribution companies by the a regulatory body (SEC -Secretaría de Electricidad) y Combustibles), prices which varied by location. While this worked well for urban consumers, 
this scheme meant that many rural and low-income households ended up paying a significant proportion of their income on electricity.

While remaining outside the orthodox energy policy agenda, demands for equity became an urgent matter of concern for the Chilean government from 2010. This year saw a massive social movement (Schaeffer \& Smits 2015) against large-scale energy infrastructural projects, including some of the largest public demonstrations since the return of democracy in 1990. This movement was seen by politicians and public authorities as expressing a widely-held discomfort with the existing energy system. In the words of a non-governmental expert commission, the Chilean energy system was seen as suffering from a "sustainability, legitimacy and governability crisis" (CCTP 2011), unable to guarantee "conditions of equity for the Chilean people" (p. 3).

At this time, Chile's energy system suffered from problems linked to the three types of justice identified in the EJ literature. From a distributional justice perspective, the location of energy infrastructure and associated negative externalities were perceived as highly uneven, with energy costs varying between location, and low-income municipalities - already suffering from other social and environmental problems - often hosting energy projects with little economic benefit to the community. Secondly, in procedural terms, the energy system as conceived was undemocratic, with the absence of mechanisms for participation and deliberation by local communities affected by the development and siting of energy infrastructures. Finally, considering recognition justice, the whole energy system was widely deemed as lacking any form of recognition of the local cultures and particularities of different communities, particularly indigenous areas, in which most energy infrastructures were located.

This process of problematization can be understood as an attempt to challenge the neoliberal frames imposed on energy policy during the dictatorship. This was achieved by connecting the issue of high electricity prices with broader demands for equity and energy justice.

\subsection{Framing}

With the arrival of the socialist Michelle Bachelet to power in 2014, this problematization was taken up by the Ministry of Energy (ME) who produced "Agenda Energía", an ambitious plan to reform in the energy sector, with the aim of fostering a "reliable, sustainable and inclusive development of energy at reasonable prices" (ME 2014). In order to turn this objective into regulation, a package of bills was put forward by the $M E$, each dealing with a specific reform proposed under the Agenda. This package included a bill called "Asociatividad" (partnership), a scheme under which companies will enable communities to participate in the economic benefits of projects. As such, an initial framing of justice claims was made: one that understood the multiple interrelated claims at the center of the social movements of 2010 as a set of clear, self-contained issues, easily differentiated from each other.

However, this bill did not find the political support to be passed to the parliament, and instead it was divided into a series of initiatives (Orellana 2015). One of these was the "tariff equity law", that occupied a prominent position in this raft of bills. The need for such a law was justified in the following terms:

One of the challenges regarding having reasonable prices derives from the fact that nowadays there is an evident and substantial dispersion in residential electricity tariffs across our territory, expressed in the fact that ... there is a difference of $76 \%$ [in tariffs, between municipalities with the highest and lowest prices of electricity]. Differences of such a magnitude are not observed in other interconnected markets. 
... Besides this there is the paradox that municipalities in which electricity generation is intensive have much higher tariffs than municipalities in which there is no generation (BCN 2016, p.3).

Within this framing, there is no explicit reference to the "inequity" of energy prices, with a first framing - and early example of economization - presenting the issue as a question of wrong prices; a framing in line with that provided by the original neoliberal reform of 1982 . In this frame, prices are not "reasonable" when compared with liberalized markets elsewhere; an economic problem that requires correction.

However, the draft also recognizes that any correction will not be driven solely by economic concerns. For "even though the price difference in electricity tariffs between municipalities derives from objective economic factors, such differences are considerably high and do not take into account other kinds of externalities" (p. 4). In introducing the proposed changes, the aim of the regulation was never just to achieve "reasonable" electricity prices, but also to address the "externalities" produced by energy infrastructures, which had been at the centre of national controversies since 2010. Beyond its economical rationality, and following Pallesen (2016), "the tariff is basically an instrument or device for achieving a valuable public good" ( $p$. $10)$, in this case, an increase in the overall equity of the electricity system.

To achieve these aims, the draft bill aimed to fulfill two objectives: "on the one hand, to reduce consumer tariffs in those municipalities that house electricity generation plants and, on the other hand, to narrow the residential electricity tariffs between different zones of the country" (p. 4). To materialize each aim, it proposed the introduction of two particular "market devices" (Callon et al. 2007) as part of the existing electricity law.

The first market device introduced a tariff discount that would recognize the contribution of areas hosting energy generation infrastructures. Such discounts were calculated on the basis of a "factor de intensidad (intensity factor), a quantity derived from the installed capacity ${ }^{2}$ of energy generated by all the infrastructures present in a particular municipality, as divided by the total number of inhabitants. Based on this "intensity factor", a certain percentage is discounted from the energy tariff, from $4.38 \%$ to $50 \%$ of the average tariff (Figure 1 ).

\footnotetext{
${ }^{2}$ Installed capacity is the maximum electricity output that an electricity generator can produce under ideal conditions.
} 


\begin{tabular}{|c|c|c|}
\hline \multicolumn{3}{|c|}{ Discount according to intensity factor } \\
\hline \multicolumn{2}{|c|}{$\begin{array}{c}\text { Intensity Factor }\left(\mathrm{kW} / \mathrm{N}^{\circ}\right. \\
\text { of regulated clients) }\end{array}$} & \multirow{2}{*}{$\begin{array}{l}\text { Discount } \\
{[\%]}\end{array}$} \\
\hline Maximum & Minimum & \\
\hline \multicolumn{2}{|c|}{$>2.000$} & $50,00 \%$ \\
\hline 2000 & $>1.500$ & $45,00 \%$ \\
\hline 1500 & $>1.000$ & $40,00 \%$ \\
\hline 1000 & $>350$ & $35,00 \%$ \\
\hline 350 & $>75$ & $17,50 \%$ \\
\hline 75 & $>15$ & $8,75 \%$ \\
\hline 15 & $>2,5$ & $4,38 \%$ \\
\hline
\end{tabular}

Figure 1: Discount according to intensity factor. Source:

Translated from the original by the authors (BCN 2016)

Second, the draft bill aims to reduce the difference in energy tariffs between high and low population areas in the country, introducing a "cross-subsidy" mechanism that would minimize this variation to a maximum $10 \%$, and distributing the cost of this intervention among all residential consumers in high population areas with consumption greater than $180 \mathrm{kWh}$ (p.5). This "cross subsidy" means that a group of consumers in densely-populated areas would pay more in their electricity bills to subsidize those in the least populated areas. This scheme would not affect the overall revenue of distribution companies, which in Chile are monopolies regulated by law. As a reform explicitly targeting equity, only high-income clients (assumed to be those with consumption higher than $180 \mathrm{kWh}$ ) would contribute to the redistribution scheme.

Both of these devices function as "valorimeters" (Calıskan \& Callon 2010), entities aimed at making a "translation of values into figures and, more precisely, into monetary amounts" ( $p$. 17). In this case, these values correspond to the equity of the energy system in the country, which requires improving the tariff conditions of rural municipalities or those hosting production infrastructures.

\subsection{Overflowing}

The draft "tariff equity law" was presented to parliament for scrutiny in July 2015. In the resulting discussion, it faced multiple criticisms and challenges, as actors attempted to redraw the government framing of the matter of concern. Beyond purely "technical" matters, such overflows could also be looking to challenge the broad framing of equity and justice enacted thus far - something we can see in three salient overflows faced by the draft bill.

\subsubsection{Are all the relevant actors included inside the frame?}


The key valorimeter of the bill, the cross-subsidy, garnered a series of critiques from MPs. These were mainly directed at the exclusion of key actors from the measure, especially those companies involved in the development of energy infrastructure. This tension became apparent as a group of mayors - who had led social movements responding to energy prices and the effects of infrastructures - were invited to testify in the parliamentary discussion. Hugo Rojas, Mayor of Puchuncaví, a municipality that houses three large coal-fired thermal power plants, claimed it was not possible to ask this bill to address the issue of externalities, as those costs were far higher than any reduction to the electricity tariff. In this, he acknowledged that the framing of the project was insufficient to tackle the injustices of the system.

Following this critique, a group of senators attempted to introduce a further valorimeter in the form of a proposal to include companies in the scheme, mandating their involvement in a fund, administered by the Ministry of Energy, which would be used for development projects within the community. This valorimeter was declared inadmissible, as it would have meant extending beyond the two original objectives of the law, and could not be reconciled with the "right" framing of this particular issue. ME personnel argued that this could, instead, be included in future regulations. With the main producers of local externalities completely excluded from the frame, this severing of overflowing ties weakened the bill's overall equity effect, reducing its capacity to address the issues raised in the problematizations described above.

\subsubsection{Is the bill technologically neutral?}

A second overflow emerged in relation to the "technological neutrality" of the draft bill. As presented, the "intensity factor" would not distinguish between different electricity generating technologies, such that municipalities hosting highly polluting coal power plants, given equal installed capacity, would receive the same discount as those housing renewable facilities.

For some MPs, this "neutrality" undermined ideas of justice, as it would be necessary to include compensation for pollution produced by energy generation, something demanded by affected communities. Responding to this argument, Minister of Energy Máximo Pacheco argued that taking a position on particular technologies would be risky, because "while there are areas ... that oppose wind power, there are others that oppose solar power. Depending on the goods that you wish to care for, not only coal based generation is polluting" (BCN 2016). Once again, equity is limited to a framing of energy as a service, without considering whether the provision of this service produces its own negative effects, also unevenly distributed.

These discrepancies in framing led to the introduction of a third valorimeter, "local generation plus". This device introduced additional compensation to municipalities effectively producing more than $5 \%$ of the country's total energy, in contrast to the second valorimeters, that considered installed capacity. This corresponds mostly to heavily-polluting coal-fired thermal plants or large hydropower dams. Such compensation could amount to a $25 \%$ reduction in local electricity tariffs, depending on their contribution to the national energy supply (Figure 2). 


\begin{tabular}{|c|c|c|}
\hline \multicolumn{3}{|c|}{ Discount according to percentage } \\
\hline \% of contribution over generated energy & Discount (\%) \\
\hline Maximum & Minimum & \\
\hline \multicolumn{2}{|c|}{$>15 \%$} & $25 \%$ \\
\hline $15 \%$ & $>10 \%$ & $20 \%$ \\
\hline $10 \%$ & $>5 \%$ & $15 \%$ \\
\hline
\end{tabular}

Figure 2: Discount according to contribution percentage. Source Translated from the original by the authors (BCN 2016)

By introducing this third valorimeter, an additional framing of the issue was embedded into the regulation, acknowledging the existence of an inequity derived from the uneven distribution of externalities associated with the concentration of energy production facilities.

\subsubsection{Is there justice for "sacrifice zones"?}

Although the bill was welcomed as a project that "makes justice", it was also criticized as being an incomplete form of justice. A group of senators representing the areas most affected by the development of energy infrastructure argued against a framing limited to the distribution of economic costs and benefits, urging parliamentarians to consider the quality of life of people living near energy infrastructures. The issue of "zonas de sacrificio" (sacrifice zones) was mentioned as a problem of "territorial justice" that was not being addressed by this law. One Senator even called the project "justicia estética" (shallow justice), because, in his opinion, it did not address the fundamental injustices of the system.

Responding to these complaints, Pacheco commented that,

In order to understand what is tariff equity it is useful to ask ourselves 'what is not tariff equity?' In this sense he signals that it is not tariff equity to deal with longterm problems [such as the current electricity pricing system] ... If we add to this that this is not a project to compensate for externalities we get a more exact vision of what this draft bill is, and this is [the issue of] why in some municipalities their tariffs are more than $80 \%$ higher than in others, and also how can we provide benefit in their electricity bills to neighbors who house energy generating capacity in their municipalities (BCN 2016)

As in the above case, this overflow was resolved by demonstrating how the entities raised by the plaintiffs fell outside the ME's frame of tariff equity. As Pacheco argued, the ME's conception of equity fell within a specific frame, and should not have been confused with other justice claims. The draft bill allowed for a mechanism facilitating a partial redistribution among residential consumers, not a vehicle to address larger issues such as "sacrifice zones". 
Having managed these overflows, in his final intervention before the draft was approved, Minister Pacheco celebrated the upcoming regulation:

The project we are discussing today makes justice. It makes justice when Chilean homes pay reasonable prices for electricity; there is justice when municipalities that generate energy are compensated by their contribution, which they make to the whole country; there is justice when we have an electricity supply with fewer power shutdowns, which is supported by clean and renewable energies; there is also justice when all the inhabitants of Chile have access to electricity in similar conditions. (BCN 2016)

This declaration is significant in how it reframes the matter of concern in this particular piece of regulation, returning to the original problematization of the issue, referring to it as "justice" and not mere financial equity.

However, the "justice" enacted by this regulation is different from that originally raised at the problematization stage. While inequities between tariffs are to be reduced, most other aspects of the original justice claims had been excluded from the regulated frame. This includes not only aspects of procedural and recognition justice, but also those directly related to distributional justice, including economic compensation for externalities paid by energy producers. This outcome was the result of the particular kind of economization undertaken by the actors, which established a narrow economic framing around the original justice claims sufficiently narrow to resist a range of possible overflows.

\section{Conclusions and policy implications}

In this paper, we analyzed the implementation of a new regulatory framework for energy justice in Chile, the "tariff equity law", which aimed to reduce the difference in costs between residential consumers in different locations. We focused on the parliamentary discussion as a means to understand this law as a process of economization comprising three steps: problematization, framing and overflowing. Problematization corresponds to the public definition of a matter of concern; framing is the process of delimiting the problem and its potential solutions; and overflowing denotes the resistance of the actors implicated in the given frame.

Tracing the process of economization, we demonstrated how a range of initial justice claims, rooted in diverse demands for affordability, sustainability, participation, and representation, were narrowed down, into a more limited version of equity. This reduction was enacted by devising a set of economic mechanisms, or "valorimeters", which were to redistribute economic costs between residential consumers. However, this framing of equity was resisted by elements originally excluded, in a process of "overflowing". This lead to some changes to the draft bill, including the introduction of a third valorimeter: "local generation plus."

Reflecting on this analysis, a contribution to the challenge of "exploring energy justice as a decision-support tool" we provide some policy recommendations based on our empirical findings.

The first recommendation relates to the nature of justice claims, which are always many things at once, a multiplicity that rarely add up to a coherent whole. Drawing on Law and Mol (Law 2004; Mol 2002), we could say that what characterizes the search for justice in the energy domain is the proliferation of non-coherent versions of such. Countering arguments that 
justice claims could comprise multiple "versions" or "kinds" that neatly support each other (McDermott et al. 2013), the justice claims we have analyzed are enacted in multiple, contrasting, even incompatible, ways. Given this multiplicity and non-coherence, in order to address justice claims in the energy sector, policy needs to enact wide framing processes in the earliest stages, such that enables it to "understand... and trac[e] the potential interconnections between production and consumption [of energy] alongside distribution and procedure" (Fuller \& McCauley 2016). These frames should reflect both the connections and trade-offs between different interpretations of what an energy system should prioritize, how it should be governed, and the time and effort required to enable a socially desirable transformation.

Against the usual critiques of economics, we believe that economization processes should occupy an important place in these framings of equity. While more explicitly "politicized" (participatory, democratic, etc.) approaches to justice claims have obvious flaws, economizations can be instrumental in enacting more comprehensive regulations that enable movement towards higher levels of energy justice. As explored elsewhere (Ballestero 2015; Pallesen 2016), used reflexively, and in dialogue with other forms of valuation, economic devices can contribute decisively to the materialization of increasing levels of social equality. "Civilized" energy markets can make a difference, but only if they are set up as spaces in which multiple justice claims (economic, political, environmental, etc.) can be properly addressed.

Given the above, we believe energy justice research has a lot to gain from incorporating elements from the analytical framework outlined in this paper. Reaching higher levels of energy justice through (or with the help of) economic devices is far from a straightforward process. Even if all actors have the best intentions, as seen in this case, the result can end up merely enacting a "shallow" justice, or further strengthening the inequities that first motivated the attempted intervention. For this reason, it is key for energy justice practitioners to engage with economizations, to understand their language and agencies, in order to (1) act as translator between economic valuations and actors carrying other forms of value, (2) contribute to their steering and redirection by making the connection and trade-offs between different framings explicit, and, if needed, (3) being able to recognize - and act, raising the alarm - if the attempted policy intervention does not contribute to higher levels of justice in the energy sector.

\section{Acknowledgements}

This research was funded by Iniciativa Científica Milenio, Núcleo Milenio de Investigación en Energía y Sociedad NS 130024 of the Government of Chile.

\section{References}

Ballestero, A., 2015. The ethics of a formula: Calculating a financial-humanitarian price for water. American Ethnologist, 42(2), pp.262-278.

$\mathrm{BCN}, 2016$. Historia de la Ley $N^{\circ} 20.928$ - Establece mecanismos de equidad en las tarifas de servicios eléctricos, Valparaiso, Chile: Biblioteca del Congreso Nacional de Chile.

Bernstein, S., 1988. Competition, marginal cost tariffs and spot pricing in the Chilean electric power sector. Energy Policy, 16(4), pp.369-377.

Breslau, D., 2013. Designing a market-like entity: Economics in the politics of market formation. Social Studies of Science.

Calıskan, K. \& Callon, M., 2009. Economization, part 1: shifting attention from the economy towards processes of economization. Economy and Society, 38(3), 
pp.369-398.

Calıskan, K. \& Callon, M., 2010. Economization, part 2: a research programme for the study of markets. Economy and Society, 39(1), pp.1-32.

Callon, M., 2009. Civilizing markets: Carbon trading between in vitro and in vivo experiments. Accounting, Organizations and Society, 34(3-4), pp.535-548.

Callon, M., 1998. The Laws of the Markets, Oxford: Blackwell.

Callon, M., Millo, Y. \& Muniesa, F., 2007. Market Devices, Malden, MA: Blackwell.

Castillo, G. \& Maldonado, P., 2004. Situación de la Energía en Chile: Desafíos para la Sustentabilidad, Santiago: Chile Sustentable.

CCTP, 2011. CHILE NECESITA UNA GRAN REFORMA ENERGÉTICA: PROPUESTAS DE LA COMISIÓN CIUDADANA TÉCNICO-PARLAMENTARIA PARA LA TRANSICIÓN HACIA UN DESARROLLO ELÉCTRICO LIMPIO, SEGURO, SUSTENTABLE Y JUSTO, Santiago de Chile.

CNSP, 1996. La Pobreza en Chile: Un Desafío de Equidad e Integración Social, Santiago: Consejo Nacional para la Superación de la Pobreza.

Fourcade, M. \& Healy, K., 2007. Moral Views of Market Society. Annual Review of Sociology, 33, pp.285-311.

Fuller, S. \& McCauley, D., 2016. Framing energy justice: perspectives from activism and advocacy. Energy Research \& Social Science, 11, pp.1-8.

Geiger, S. et al., 2014. Being concerned about markets. In Concerned Markets: Economic Ordering for Multiple Values. London: Edward Elgar Publishing.

Le Grand, J., 1991. Equity and Choice:: An Essay in Economics and Applied Philosophy, London: Routledge.

Hall, S.M., Hards, S. \& Bulkeley, H., 2013. New approaches to energy: equity, justice and vulnerability. Introduction to the special issue. Local Environment, 18(4), pp.413-421.

Heffron, R. \& Talus, K., 2016. The evolution of energy law and energy jurisprudence: Insights for energy analysts and researchers. Energy Research \& Social Science, 19, pp.1-10.

Huneeus, C., 2007. Argentina y Chile: el conflicto del gas, factores de política interna Argentina / Argentine domestic policy and the conflict over gas exports to Chile. Estudios Internacionales, 40(158), pp.179-212.

Jenkins, K. et al., 2016. Energy justice: A conceptual review. Energy Research and Social Science, 11, pp.174-182.

Latour, B., 1983. Give me a laboratory and I will raise the world. In Science Observed. London: Sage, pp. 141-170.

Latour, B., 2004. Why Has Critique Run out of Steam? From Matters of Fact to Matters of Concern. Critical Inquiry, 30(2), pp.225-248.

Law, J., 2004. And if the global were small and noncoherent? Method, complexity and the baroque. Environment and Planning D: Society and Space, 22(13-26).

MacKenzie, D., 2007. Do Economists Make Markets? On the Performativity of Economics, Princeton: Princeton University Press.

McDermott, M., Mahanty, S. \& Schreckenberg, K., 2013. Examining equity: A multidimensional framework for assessing equity in payments for ecosystem services. Environmental Science \& Policy, 33, pp.416-427.

ME, 2014. Agenda de Energía: Un desafío país, progreso para todos, Santiago de Chile: Ministerio de Energía - Gobierno de Chile. 
Miller, C., Richter, J. \& O'Leary, J., 2015. Socio-energy systems design: A policy framework for energy transitions. Energy Research \& Social Science, 6, pp.29-40.

Mol, A., 2002. The Body Multiple: Ontology in Medical Practice, Durham, NC: Duke University Press.

Orellana, G., 2015. Gobierno zanja la discusión por ley de Asociatividad y divide proyecto en tres partes. Pulso, p.4.

Özden - Schilling, C., 2015. Economy Electric. Cultural Anthropology, 30(4).

Pallesen, T., 2016. Valuation struggles over pricing - determining the worth of wind power. Journal of Cultural Economy, pp.1-14.

Schaeffer, C. \& Smits, M., 2015. From matters of fact to places of concern? Energy, environmental movements and place-making in Chile and Thailand. Geoforum, 65, pp.146-157.

Sovacool, B. \& Dworkin, M., 2015. Energy justice: Conceptual insights and practical applications. Applied Energy, 142, pp.435-444.

Suddaby, R., 2006. From the Editors: What Grounded Theory is Not. Academy of Management Journal, 49(4), pp.633-642.

Tomei, J. \& Gent, D. eds., 2015. Equity and the energy trilemma: delivering sustainable energy access in low-income communities., London: International Institute for Environment and Development,.

Wautiez, F. \& Llavero, A., 2002. La equidad socio-ambiental en Chile: Una tarea pendiente. In Línea de Dignidad: Desafíos sociales para la sustentabilidad. Santiago: Programa Cono Sur Sustentable.

Welton, S., 2016. Clean Energy Justice. University of Colorado Law Review, Forthcoming. 